\title{
Natural Farming System Sustainability of Paddy Fields in Morotai Island Regency
}

\author{
Ranita Rope ${ }^{1}$, Jangkung Handoyo Mulyo ${ }^{2}$, Masyhuri ${ }^{2}$, Lestari rahayu \\ Waluyati $^{2}$
}

\author{
${ }^{1}$ Fakultas Pertanian Universitas Muhammadiyah Maluku Ternate, Indonesia \\ ${ }^{2}$ Fakultas Pertanian Universitas Gadjah Mada Yogyakarta, Indonesia
}

\begin{abstract}
Various parties intensively conduct the increasing awareness trend and mindset change on environmental and healthy food consumption patterns. The environmental resources damage problem, watertight agricultural land, human health, unhealthy food, contributes to global warming and in aggregate has an impact on diversity, sovereignty, independence and sustainability of food sources.Back to nature is a developed solution to overcome the negative externalities various effects. These research conducted to assessing natural paddy fields farming systems sustainability as a natural local food source in Morotai Island Regency.The analysis method using indicator basis was adapted from the Sustainability Assessment of Farming and the Environment (SAFE) model and the Farmers Sustainability Index (FSI) model on 200 respondents samples. The results explain that the natural farming system of paddy fields sustainable on economic, socio-cultural and environmental dimensions. There are assessment indicators attributes which are full local wisdom of economic, socio-cultural and environmental dimensions based on farmers and regions specific indicators in determining sustainability of paddy field natural farming system level holistically.Therefore, the novelty of these study is that the natural farming system is a world agricultural tradition that has been crushed by agricultural globalization but is still sustainable in Morotai Island Regency and has sustainability indicators which are full specific farmers and regions local wisdom. Keywords - Sustainability index, local wisdom, natural farming system, paddy fields, Morotai Island.
\end{abstract}

\section{INTRODUCTION}

Starting from population theory of Malthus that population growth is faster than food availability, so famine disasterfears encourage experts to find a solution. Various agricultural systems are developed, one of which is green revolution technology known as inorganic (conventional) farming systems. Studies that are not holistic and mature give rise to a variety of negative externalities. Various problems occur due to green revolution technology, that isenvironmental resources damage problem, watertight agricultural land, human health, unhealthy food, and contribute to global warming and in aggregate have an impact on inequality in diversity, sovereignty, independence and sustainability of food sources.

Mindset changes and increasing awareness trends of an environment and healthy food consumption patterns are intensively carried out by various parties. Back to nature is a developed solution to overcome the negative externalities variety due to environmental damage and unhealthy food. Saragih (2016) explained that global warmingconcerns threat, hungercatastrophe, and food security continue to be discussed. The Global Hunger Index report (2016), there are 795 million people $(10.6 \%$ of the earth's population) sleeping hungry. On the other hand, WHO states that 1.6 billion people who are overweight and 600 million obese people. These means that hunger occurs not because of insufficient food production throughout the world, but due to inequality in food distribution, inability to produce due to the lack of land to plant and the failure to buy healthy food.

Supporting world orientation changes to increase food availability is no longer affected by quantity trends productivity but instead on food production quality sources. Wigenas antana and Waluyo (1991) had voiced the natural farming system as the best alternative agricultural system in Indonesia. The natural paddy farming system is one of the oldest farming systems in the world. Originally a primitive agricultural system developed into a system of shifting, subsistence farming, as known as the dry land traditional farming system and was crushed by agriculture globalization. Fukuoka (1978) has introduced the concept of natural agriculture, both vegetables, beans, paddy field, rye, and others. Further exp lained by Fukuoka that natural farming systems are holistic agricultural systems.

The natural agricu ltural system principle implies that natural power can regulate plant growth. There are four basic principles in developing the natural farming system 
according to Fukuoka (1978), that is; 1)without-tillage; 2) do not use fertilizers, herbicides and synthetic chemical pesticides; 3) don't use hybrid seeds. Land naturally developed does not respond to hybrid seeds, so it must use local seeds; 4)do not do intensive irrigation water. Explained by Rope and Umasugi(2014) that the paddy fields natural farming system developed in Morotai Is land Regency is used without any fertilizer. The average production reaches 4.5 tons, economically efficient because it uses seed inputs and labor.

Based on developing the natural agricultural system principles by farmers on Morotai Island, it has low productivity but is thought more sustainable in meeting farmer householdfood needs. The sustainability allegations of natural paddy fields farming systems are related to several important things, among others; 1)the farming has characteristics of tropical forest dryland ecosystems, meaning that paddy fields developed resistant to drought; 2)economically efficient, because it minimizes external inputs, and maximizes internal inputs; 3) preservation of local seedsqualityvariety, where the best solution to maintain genetic authenticity of seeds variety to be preserved in their original habitat; 4)having initial knowledge and social traditions with mutual cooperation culture and joint harvesting in the future time dimension so it not only measures short-term but long-term interests; and 5) allegedly as the natural and nutritious food source can meet farmer households food needs and easy access to reach specific communities in the border area, because as an area that requires high transportation costs to supply rice products from regionoutside. Thus the sustainability research of natural paddy fields farming systems in Morotai Is land District is essential to be preserved.

\section{LITERATURE REVIEW}

\section{Economic and Social Culture Values of Farmers}

The farmer's phenomenon and the non-market-oriented agricultural system still applies today natural farming systemsregional communities, when information and technology access has developed rapidly, but changes in agricultural globalization do not crush paddy fields natural farming system farmers' perception. Paddy field is not commercialized because there is a strong socio-economic value of farmers' culture as life culture. These phenomenon affected by farmers' perceptions of their farming lives. In Galela farmers, North Halmahera Regency, farmers' perceptions were classified based on the concept of farming and agricultural crop type known as Doro de Raki. Doro means the subsistence tradition and Raki are estate-based as sets or investments.

The fulfillment of income needs derived from annual plants, perennials, gardening plants such as coconut, cloves, nutmeg, chocolate, coffee, and others are farming concepts known as Raki or plantations which also means investment or farmer's family future life assets. Seasonal plants such as food secondary crops, tubers, and vegetables are fulfillingsource non-market-oriented daily consumption needs that are subsistently lived. These were done from generation to generation as explained by Bareta (1917) that the cultivation system developed in Halmahera and Morotai was not adhering to the plantation method. So that, it is not known the profit or loss in paddy field farming. The farming communities are mixed social organization entities in social structures because the communities have many relationships with various social organizations (Rouf et al., 2015). Families, groups, kins man, households and homes, and others are farming communityelements. The traditional farming communities characteristics using manual labor, individual production facilities, the unplanned division of labor, readily available land, from families and using natural raw materials and autonomyachieving.

Empirically, the natural farming systemscharacteristics are farmers have Bariwisdom or cooperation when planting paddy fields and profit sharing during harvesting activities (Rope, 2013). There is socio-cultural wisdom of economic value. The BariWisdom can overcome labor shortages experienced by the agricultural sector, especially for planting workers who require a considerable amount of labor and without wages. Likewise at harvesting stage activities taken during harves ts for months due to traditional harvesting tools used, but with shared harvesting wisdom and profit sharing being a solution without expensive technology capital can meet harvest labor needs and is socio-cultural wisdom economical regarding meeting fellow food needs. Every human being is responsible for other human food needs (Creswel and Martin, 1998).

\section{Agricultural SystemsSustainability}

Various sustainability studies have been conducted. Sustainability measurementis very complicated. The measuring is not measurable: sustainability index survey (Bohringer and Jochem, 2007). Reviewing 11 sustainability index methods to measure sustainability indexes, but failing to fulfill the study based on scientific criteria. The develop ment trend that requires sustainability aspects is vital to develop various studiescontinuously. Likewise in the dialysis agricultural system sustainability study by referring the consistent and objective approach indicators identification and selection (PC \& I) using the Sustainability Assessment of Farming and the Environment (SAFE) framework assessment (Van Cauwenbergh et al.,. 2007). The framework is designed in 
three spatial levels and includes three pillars of sustainability, that is the environmental, economic and social.

Farming sustainability research was also conducted previously by Gowda and Jayaramaiah (1998) using indicators grouped in three dimensions of sustainabilityby developing a Farmer Sustainability Index (FSI). A frame work similar to SAFE, but FSI is equipped with an analysis formula. Gowda and Jayaramaiah explained that composite indicators greatly determine the accuracy of sustainability. There were ten traditional agricultural indicators on ecological, economic and social aspects which tended environmental compared than conventional farming systems (Rasul and Thapa,2003). The behavior of adding more organic content, higher local inputs, and providing balanced food.

Sustainability research refers to the Farmer Sustainability Index (FSI) in India with 40 items, including insect control, disease control, weed control, soil fertility management, soil erosion control, and related practices relevant to local farmerconditions. The FSI was developed to measure sustainable practices application by traditional Indian rice farmers. The results illus trate the various values of the Farmer Value Index between two groups of rice farmers; conventional farmers and more sustainable farmers. The first farmer type of index score is 23.95 , and the last is 70.06, indicating that farmers who implement sustainable farming systems are more durable than conventional farmers. Likewise, the new agricultural sustainability indicators system is proposed in dynamic weight calculations in China. The three main ind icators are used to measure the index valuethat is ecosystems that are indisputable, economically viable, and socially acceptable. The three indicators are then integrated into the overall systemindex value using geometric averages (Mohamed et al., 2016).

In principle, the number of sustainability indicators must be carefully studied and determined so that they can measure and describe thesustainability condition. The useful indicatorsselection is the success key of each sustainability evaluation. Hayati et al., (2010) explained that as much as possible efforts to evaluate sustainable agriculture on the aggregate level with some indicators that are almost comprehensive have not been able to measure sustainability capability at the farm level. Therefore, Hayati et al., (2010) further recommended the indicators used for agricultural sustainability must be site-specific. The criteria for selecting 14 agricultural sustainabilityindicators in developing countries are clearly from economic, social and ecological dimensions (Zhen and Rotray, 2003). Thus, the farm system sustainability is assessed as representative if it is based on specific indicators of farmers and regions.

\section{ANALYSIS METHOD}

The study was conducted in Morotai Island Regency, North Maluku Province. The research areaselection is made by purposive sampling, in 5 districts; East Morotai, Morotai Jaya, North Morotai, South Morotai, and South West Morotai. In the whole region, some farmers preserve the natural farming system of paddy fields. The farmer selection using random sampling in $20 \%$ of the 1000 farmer populations that maintain the natural farming system of paddy fields. So that a sample of 200 respondents was obtained.

Answering the aim of the study to assess natural farming systems sustainability in the economic, socio-cultural and environmental dimensions using farmers-specific analysis of the region adapted to the combination concept of Van Cauwenbergh's, N., et al (2007) through SC \& I models using The Sustainability Assessment of Farming and the Environment (SAFE) framework and the farmers sustainability index (FSI) model refer to Gowda and Jayaramaiah (1998); Rasul \& Thapa (2004); Terano et al. (2015); Mohamed et al., (2016). Indicators Formulated consists of 13 indicators that are developed, modified and adapted based on agricultural sustainability consensus and findings of various research results adapted to potential regional specific conditions in preserving natural paddy fields. For this reason, the formulation of sustainability indicators as shown in Figure 1. 


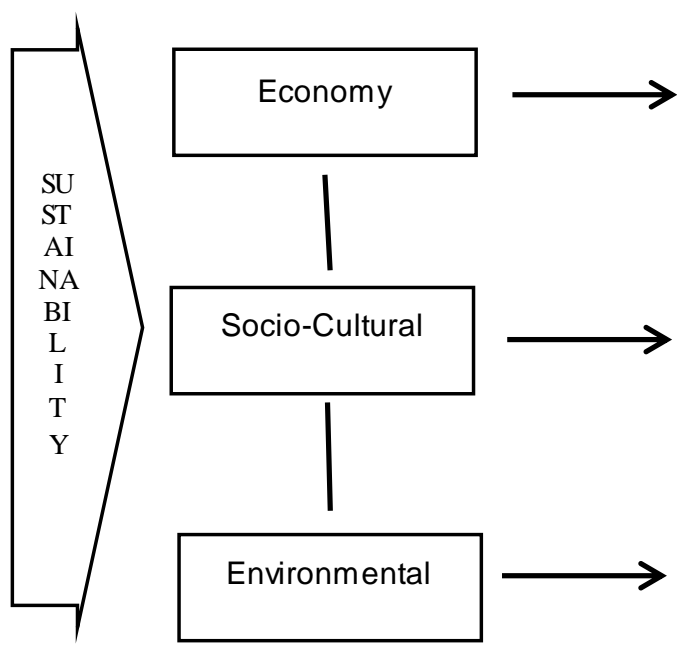

Food adequacy of farm household

Food productionSource

Productivity

Own input availability

Income Sources

Harvest $w$ isdomand shared prof it sharing

Cooperation culture

Justice for fulfilling food needs

Crop yield security

Groundwater quality

Soil fertility

Type of irrigation

Use of fertilizersvarieties, pesticides, and herbicides

Fig.1: Sustainability indicators formulation of natural paddy fields farming systems

The sustainability indicator formulation of paddy field natural farming system is analyzed by the sustainability index using Go wda and Jayaramaiah (1998); Rasul \& Thapa (2004); Terano et al. (2015); Mohamed et al., (2016) formula developed as follows:

$$
Z i j=\left(\frac{Y i j-M i n Y j}{M a k s Y j-M i n Y j}\right)
$$

Where is:

Zij $=$ Unit of standard value on respondent $i$ on the component to $j$.

Yij: Respondent's value to $i$ to component $j$

The further formula used is:

$$
S l i=\frac{\Sigma(\text { Zij.Sj })}{\text { TotalNilai }} \times 100 \%
$$

Where is:

SIi=Sustainability index of farmers to $i$

$\mathrm{Z} i j=$ Standard value unit on the respondent to $i$ on the component to $j$

Sj=Value scale of the element to $j$

The sustainability measurement is based on the index value criteria as shown in Table 1.

Table 1. The index value criteria of sustainability indicators

\begin{tabular}{cc}
\hline Index Value & Criteria \\
\hline $80.01-100$ & Very Sustainable \\
$60.01-80$ & Sustainable \\
$40.01-60$ & Less Sustainable \\
\hline
\end{tabular}

\begin{tabular}{ll}
\hline $20.00-40$ & Unsustainable \\
\hline
\end{tabular}

Furthermore, the testing was an analys is based on the $t$-test where $\mathrm{H}_{0}: \mu<60.01 ; \mathrm{H}_{1}: \mu \geq 60.01$. If $\mathrm{F}_{\text {count }}>\mathrm{F}_{\text {table: reject }} \mathrm{H}_{0}$ means sustainable; If $\mathrm{F}_{\text {count }} \leq \mathrm{F}_{\text {table }}$ : accept $\mathrm{H}_{0}$ means unsustainable.

\section{RESULTS AND DISCUSSION}

Natural, human and capital resources which unique characteristics on Morotai Island are God's gift to be grateful. Many things can be explored to become future agricultural models. The future that is described and heralded at this time, by world geographers that in 2045 there will be a drought due to the dryness of the ten largest springs in Asia followed by increasing population, requiring adequate food availability. Indirectly affecting Indonesia as one of the Asian countries to think about the sustainability of the region-specific agricultural system.

Future phenomena require drought-resistant agricultural systems, maximizing internal and minimizing external inputs are a necessity in agriculture current globalization. But in Morotai Island, which underdeveloped, backward, and poorestregions, evidentlystored natural resources which are truly extraordinary and require human resources in developing representative research. Its physical nature, its farmers, are full of wisdom, its genetic diversity is maintained from destructive modern technology. So that, it can be claimed that the natural paddy farming system is the only agricultural system that can fulfill sustainability criteria holistically. Is the natural paddy farming system characterized by environ mentally friendly and conditions 
with farmers' wisdom, can be econo mically sustainable, socio-cultural and environmental?

The results will discuss in detail onpaddy fields natural farming system sustainability in three dimensions that is economical, socio-cultural and environmental. There are 13 indicators described in the method section and are assessed based on the number of attributes. The detailed analysis results are shown in Tables 2 and 3.

Table 2. The results analysis of sustainability index

\begin{tabular}{lccc}
\hline & \multicolumn{3}{c}{ SustainabilityDimensions } \\
\cline { 2 - 4 } & Economy & Socio-Culture & Environmental \\
\hline $\mathrm{N}$ & 200 & 200 & 200 \\
Mean & 63,64 & 72,41 & 67,19 \\
Median & 68,49 & 72,38 & 63,33 \\
Modus & 82,64 & 100,00 & 100,00 \\
Standard Deviation & 17,32 & 24,26 & 18,97 \\
Minimum & 23,78 & 22,74 & 30,00 \\
Maximum & 97,63 & 100,00 & 100,00 \\
Total & 12727,47 & 14481,55 & 13438,89 \\
\hline
\end{tabular}

Source: Primary data processed, 2018

Table 3. Results of one sample t-test for sustainability in economic, socio-cultural and environmental aspects

\begin{tabular}{cccc}
\hline Sustainability index & Mean & $t$ count & P value \\
\hline Economy & 63,64 & 11,128 & 0,000 \\
Socio-Culture & 72,41 & 13,058 & 0,000 \\
Environmental & 67,19 & 12,808 & 0,000 \\
\hline
\end{tabular}

Source: Primary data processed, 2018

The results of the economic, socio-cultural and environmental index analysis as the aggregate obtained mean values seen in Table 1 in intervals of 60.01-80.00. The results of one sample $t$-test in Table 2, obtained $\mathrm{t}$ count $>$ $\mathrm{t}$ table $=2.576$ at the confidence level of $1 \%$, so it was concluded that $\mathrm{H}_{0}$ was rejected and $\mathrm{H}_{1}$ has accepted, ie, $\mu \geq$ 60.1 means that the natural farming system of paddy fields is economical, socio-cultural and environmentally sustainable.

The results explained that the indicator criteria characteristics in economic dimension are met with five indicators, that is food sufficiency, food productionsources, productivity, own inputsavailability, and incomesources - the farmerwisdom in fulfilling household foodadequacy with thefoods variety available besidespaddy fields. Various food sources include bananas, cassava, sweet potatoes, taro, and sago. These are supported by multiple food consumption patterns wisdom from generation to generation and still maintained. The farmerorientation to anticipate food production sources is not focused on monoculture productionquantity but is oriented towards polyculture. Low productivity but maximizes internal inputs wisdom with own inputs availability and minimizes external inputs. Thus low productivity is not claimed to be low quality because household food needs fulfill it. If more deeplystudied, why does it reach high production but farm household food needs are not sufficient? These means, it is economically fulfilled if food needs are adequate and not economical if shortage. Thus the mindsetchange about productivity and income is not the permanent indicator in sustainability measurementof the economic dimension but is adjusted to farmers and region-based indicators.

The socio-cultural dimensionsustainability has four indicators. Farmers have socio-cultural wisdom in preserving the natural farming system of paddy field. The wisdom Indicators of shared harvesting are one of many wisdom empires that strongly support the natural farming system of paddy fields sustainability. When the harvest season arrives the landowner'sfarmer, who are ready to harvest invite kinsman and neighbors who do not plant paddy fields to participate in collecting together and sharing their crops, this means that every farmer has a humanitarian responsibility towards the food needs of kins man and neighbors. Every hu man being is responsible for other human food needs (Creswell and Martin, 1998). Besides, harvest labor need will be fulfilled without cash wages but with the intended wisdom. So that, the socio-cultural tradition can be economic value because it maximizes internal potential.

The BariW is dom or cooperation culture is the world peasant tradition carried out when planting paddy fields. For generations, it is still sustainable in Morotai Island 
Regency. This can streamline labor without being paid for planting stageneeds. The socio-cultural values achieved from this stage are influential personalities that remain sustainable. So that, shortages of laborneed or farm labor is not experienced by paddy field farmers. Other socio-cultural values that support the natural paddy rice farming systemssustainability are justice fulfillment of food needs and crop yield security. The natural paddy farming system with the wisdom variety protects farmers from not qualified food availability, protected from various imported products because farmers can meet food needs in quantity and quality.

Environmental dimension sustainability indicators consist of groundwater quality, soil fertility, irrigation systems, and fertilizers type used pesticides and herbicides. Farmers have near gardens, and water sourcessurrounded. These affect the groundwater quality is still maintained, thus forming the non-intensive perception-behavior in irrigation systems use. Likewise with soil fertility, because the groundwater quality supported indirectly affects the soil fertilitylevel. Wisdom does not use fertilizers, pesticides, and herbicides to keep agricultural lands protected from the negative externalities of using fertilizers, pesticides, and synthetic chemical herbicides. These support the natural paddy field farming systemsustainabilityin Morotai Island Regency; it is sustainable on the economic, socio-cultural and environmental dimensions. Therefore, the only agricultural system claim of inputs, processes, and outputs used is truly sustainable holistically.

\section{CONCLUSIONS}

The natural paddy farming system is theworld agricultural systemtradition and crushed by agriculture globalization but is still sustainable in Morotai Island Regency. The results and discussion concluded that the natural farming system of paddy fields is economical, socio-cultural, and environmental dimensions sustainable. There are assessment indicators attributes which are full local wisdom of economic, socio-cultural and environmental dimensions based on farmers and regions specific indicators in determining sustainability of paddy field natural farming systemlevel holistically.

\section{REFERENCES}

[1] Bareta,J.M., 1917. Halmahera En Morotai, Bewerk near memorie van den Kapitein van den Generalen Staf, Nederland.

[2] Bohringer, C., and Jochem, P., 2007. Measuring the immeasurable: A Survey of Sustainability

Indices. Ecological Economics 63:1-8

[3] BPS,2017. Pulau Morotai Dalam Angka, Daruba.
[4] Creswell, R., dan Martin, F.W., (1998). Dryland Farming: Crops \& Techniques For Arid Regions.

Diakses bulan september 2016. www.researchgate.net.

[5] Fukuoka, M., 1978. Revolusi Sebatang Jerami; sebuah pengantar menuju pertanian natural farming,.Judul asli The One-straw revolution :an introduction to natural farming, alih bahasa, Yayasan obor Indonesia , Cet.I; Yayasan Obor Indonesia, Jakarta.

[6] ----------, 1985. The Natural Way of Farming The Theory and Practice of Green Philosophy.

Tlanslated by Frederuc P Metreud. Published by Japan Publication,Inc. Tokyo and New York.

[7] Gowda, M.J.C and Jayaramaiah, K.M., 1998.

Comparative evaluation of rice production

systems for their sustainability. Agriculture Ecosystems \& Environment69; 1-9. ELSEVIER

[8] Murid, 2010. Dari Doro Ke Raki; Ekonomi Gender dan Transformasi sosial Pertanian Orang Galela. Jurnal KOMUNITAS, ISSN 2086-5465. Universitas Negeri Semarang.

[9] Rasul, G., and Thapa, G.B., 2004. Sustainability of ecological and conventional agricultural systems in Bangladesh: an assessment based on environmental, economic and social perpectives. Agricultural System 79: 327-351.

[10] Reijntjes, C.Haverkort B, and ann Waters-bayer 1992. Farming For The future; and introduction to low- eternal-input and sustainable agriculture, edisi Terjemahan Bahasa Indonesia, oleh Sukoco, Y., Kanisius Yogyakarta.

[11] Rope,R., 2007. Konsep Pertanian alami (natural farming): Sebuah Perpektif, Jurnal Sains, edisi

I Volume 1, ISSN Universitas Muhammadiyah Maluku Utara.

[12] Rope, R., Sri Widodo., Djuwari., 2008. Analis is Usahatani Pada Sistem Pertanian Alami

(Natural Farming) Padi Ladang di Kabupaten

Halmahera Utara. Jurnal Ageoekonomi

Volume 15 No 2. Universitas Gadjah Mada Yogyakarta.

[13] Rope, R., 2013. Karakteristik Sistem Pertanian Alami (Natural Farming) Padi Ladang di

Kecamatan Pulau Morotai. Journal Agrikan. ISSN:1979-6072, Volume 6, Edisi 2, UMMU Press. Ternate.

[14] Rope,R dan Umasugi,L.,2014. Efisiensi Ekonomi Sistem Pertanian alami (natural farming) Padi ladang Di Kabupaten Pulau Morotai, Jurnal AGRIKAN ISSN 1858-0416 volume 2, Edisi 
1. Fakultas Pertanian Universitas Muhammadiyah Maluku Utara.

[15] Saragih,H.,2016., Hari Pangan Sedunia 2016: Harga Pangan Melambung,Impor Meningkat dan Jumlah Petani Terus Menurun. Pidato Peringatan Hari Pangan Sedunia. Diakses bulan Oktober 2016. www.spi.or.id.

[16] Suhartini,2007. Kajian Keberlanjutan Sistem Usahatani Padi Semi Organik Di Kabupaten Sragen. Disertasi S3 Program Pasca Sarjana Fakultas Pertanian UGM. Tidak dipublikasikan.

[17] Suyatno,A.,2015. Efisiensi dan Keberlanjutan Usahatani Padi Pada Berbagai Agroekosistem di Kabupaten Mempawah. Disertasi S3 Program Pasca Sarjana Fakultas Pertanian UGM. Tidak dipublikasikan.

[18] Terano, R., Mohamed, Z., Shamsudin, M.N., and Latif, I.Abd.,(2015). Farmers Sustainability Index: The Case of Paddy Farmers in State of Kelantan, Malaysia. Journal of the International Society for Southeast Asian Agricultural Sciences. ISSAAS Vol.21, No. 1: 55-67.

[19] Van Cauwenbergh, N., Biala, K.,Bieders,C., Brouckaert,V., Franchois,L., Garcia Cidad,V., Hermy, M., Mathijs, E., Muys, B., Reijnders,J., Sauvenier, X., Valckx,J., Vanclooster, M., Van der Veken, B., Wauters,E., Peeters, A., (2007). SAFE---A hierarchical framework for assessing the sustainability of agricultural systems. Agriculture, Ecosystems and Environment 120;229-242.

[20] Wigenasantana, M.S., dan Waluyo, T.,1991.,Prospects of Nature Farming For Rice Production in Indonesia. First International Conference on Kyusei Nature Farming, Proceedings of the conference at Khon Kaen University, Khon Kaen, Thailand, October 17-21 1989. Diterbitkan Tahun 1991 di Washington DC. 